\title{
A Narrative Inquiry of Identity Construction in a Post-Colonial Context: Hybrid Identity of a Young Generation Hongkonger
}

\author{
Jingmin Yang \\ Master of Applied Linguistics, The University of Melbourne, Wuhan, Hubei, China
}

\begin{abstract}
Identity construction is a complex issue, especially for Hongkongers. Due to historical reason, Hongkongers are regarded to have multiple languages and dual identities, which is hybridity of Chinese (eastern) culture and English (western) culture. Based on the method of narrative inquiry, this study explores how a young generation Hongkonger constructs her identity in a post-colonial context and provides evidence of Hongkonger's hybrid identity. On the one hand, Hongkongers desire permission to be accepted in the certain cultural communities. On the other hand, they are excluded by both the Chinese community and the English community from a cultural point of view, which leads to localism in Hongkong. As a result, they are like cultural orphans wandering in the cultural "in-between" space.
\end{abstract}

Keywords: Narrative inquiry, Hybrid identity, Hongkonger.

\section{Introduction}

Identity is about how we define ourselves, how we interact with others in the world, and others' attitudes towards us (Jackson, 2014). It is not innate but developed with the experience of an individual's whole life (Beijaard et al. 2004). Given the fact that identity is complex and dynamic (Jackson, 2014), it is necessary to analyze this complicated issue with useful methodology. One useful approach is narrative enquiry, which aims to elicit the interviewee's memory of critical events that changed the participant's mind about selfcognition or challenged the participant's perception of world views (Webster \& Mertova, 2007). Based on the method, this study will explore how a young generation Hongkonger constructs her identity in a post-colonial context.

The identity of Hongkongers is controversial because of the historical influence. Since the long period of the British colony has greatly influenced the lifestyle of Hong Kong people and the culture of Hong Kong, Hongkongers have multiple languages and identities (Hobova, 2016). The young generation of Hongkongers is able to speak English, Cantonese, as well as Mandarin, with an advanced language proficiency level. The official languages of Hongkong are also English and Chinese. As language always links to identity, the Hongkonger's identity is usually regarded as dual and hybridity of Chinese and English. Nowadays, the young generation of Hongkongers uses "Chinese Hongkonger" and "Hongkong Chinese" to indicate they belong to a unique community (Hobova, 2016). Some scholars argue that localism is rampant in Hong Kong, which presents the strong self-determination of Hongkongers (Veg, 2017). Despite so many views and opinions of the identity of Hongkongers, the agreement on the complexity and diversity of Hongkonger's identity has been reached.

With the analysis of the narrative from the participant, this study will investigate how a young generation Hongkonger constructs her identity in a post-colonial context, and provide evidence of the dual and hybrid identity of Hongkongers.

\section{Method}

Data in this research were taken from a 30 minutes narrative enquiry, conducted on the application Zoom on the 8th of May 2021 at $6 \mathrm{pm}$ and recorded through a computer. Both the interviewer and interviewee were in private areas to avoid noise and distractions. The questions were designed before the interview, which is listed in the appendix. The interviewee was shown to the questions and was permitted to modify the questions before the interview. Plus, the participant signed the consent form, allowing the researcher to use the data for the purpose of academic study. Based on the narrative from the participant, not all the questions were asked and the question order was adjusted according to the specific situation.

The participant (Kola) is a 20-year-old female undergraduate student, majoring in psychology and linguistics in her first year at the University of Melbourne. Kola was born and grew up in Hongkong, whose parents are both local Hongkongers, so she can speak Cantonese fluently. She has been studying English and Mandarin since childhood (around 3 years old), so she is able to speak English and Mandarin with a high language proficiency level. In grade four of primary school, Kola went to the United States for a year of exchange, which helped her identify the differences between British English and American English. In high school, she went to Xian (a provincial capital city of Shanxi province in Mainland China) for an exchange for one year, which further developed her mastery of Mandarin.

Based on the analytical framework according to Labov and Waletzky's (2003), the content from Kola will be analyzed to associate with the relevant structure: Abstract, Orientation, Complicating Action, Evaluation, Resolution, and Coda.

\section{Analysis, Findings, and Discussion}

Transcription key used below

(.) short pause (..) longer pause 
.hhh inhale hhh exhale

? rising intonation . falling intonation

@@ laughter yyy-xxx repair

yyy emphasis/stress “yyy” reported speech or thought

Extract 1 below presents her identity related to the Chinese.

1) I've been to Xian for an exchange in my high school.

2) My classmates are friendly, so I usually come to them.

3) And we always talk about some stars, idols, and romantic novels, youknow.@@

4) I thought I er... They won't talk to me, but actually we become friends.

5) It's a really happy time, I think.

This is an experience as an exchanged student in Xian, Mainland China. Kola thought her classmates in Mainland China would not like to talk to her (line 4), but Kola became friends with her classmates and regarded this experience as a happy time (line $4 \& 5$ ). Kola and her classmates had the same hobbies and interests: stars, idols, and romantic novels, so there is an invisible bond that connects them together, which indicates that they have sameness. Besides, Kola came to her classmates on her initiative, presenting that Kola had a desire to be a member of the class. According to Bond and King (1985), Chinese identity is cultural rather than political, thus providing a unique spiritual pillar that inspires every individual of Chinese identity. Because of this spiritual link, Kola feels sameness with Mainland Chinese and hopes to be part of the group.

Extract 2 below shows the difference that Kola identified from Mainland Chinese.

1) I do identify myself as a Hongkonger but not Chinese from a cultural perspective.

2) Like when we are speaking in different languages.

3) Although I'm fluent in mandarin, my mother tongue is still Cantonese.

4) Most of the time I speak Cantonese with my friends and family.

5) And like when I see some Mainland China tourists in Hong Kong.

6) I can identify them at first glance.

7) Cause we have really different lifestyles.

8) Like, many tourists from Mainland China speak very loudly.

9) I don't know why because it's very noisy and it's in front of the public.
10) Like in the metro stations. It's really excruciating. hhh

11) This is how I feel different from the Chinese culture.

This extract forms a longer narrative that can be analyzed based on the framework of Labov and Waletzky (2003). The narrative comprises the following elements of the structure:

Orientation: Kola stated that she identified herself as a Hongkonger rather than a Chinese (line 1), which implies that she felt the difference between Hongkongers and Mainland Chinese.

Abstract: Kola thought that she spoke different languages with Mainland Chinese and they had different lifestyles, indicating that they shared different linguistic and cultural backgrounds (line 2 \& 7). Kola could speak a mixed language using English and Cantonese while Mainland Chinese failed to do so.

Actions: Kola described her language usage situation, as she spoke Cantonese with her friends and families (line 4). Kola also narrated that some Mainland Chinese spoke very loudly in metro stations, which is also an action (line 8).

Evaluation: Kola explained that why she could identify Mainland Chinese tourists at first glance. The reason was the loud voice of the tourists, which seemed to drove her crazy (line 5-6, 8-10). She also explained the difference between her and the tourists, not only because of the lifestyle, but also the language used in daily life (line 3 ).

Coda: Kola argued again that there was distinct difference between Hong Kong culture and Mainland Chinese culture.

Through the narrative, there are two explanations of the difference between Kola and Mainland Chinese, which contributes to her perception as a Hongkonger rather than a Chinese. On the one hand, Cantonese is the local dialect rather than Mandarin, which is commonly used by Hongkongers rather than Mainland Chinese. Because of the strong connection between language and identity (Benatti \& Tarantini, 2017), language differences will naturally lead to cultural differences. On the other hand, lifestyle is a subunit of culture or the culture is represented by a vivid lifestyle. From Kola's point of view, speaking with a loud voice in front of the public is unbelievable and would have a negative impact on other passengers in the metros, but some Mainland Chinese tourists regard it as a common behavior, which is conflicting with Kola's opinions and views, therefore making Kola feel the cultural shock (Oberg, 1960) and separate herself with Mainland Chinese.

Hence, in terms of Chinese identity, Kola feels both sameness and difference with Mainland Chinese, which proves the complexity of Kola's identity as a young generation of Hongkongers. The same circumstance also happens on the identity related to English identity (including British English identity and American English identity).

Extract 3 below presents her identity related to English.

1) In fact, I have a western social circle. 
2) Some of my relatives are Australian, I feel comfortable when I live with them.

3) Like for pop cultures, I think it's more like the West.

4) People like western movies, singers, and so on.

5) I can get some haha points in the movies, you know. @@

6) And my favorite movies are Harry Potter, both I and my cousins are super fans.

6) But you know, the movies from Mainland China are er... terrible?

7) At least the media shows like this, so... I don't watch them, yeah, I don't like it.

This narrative is about how Kola gets along with Australian relatives. Kola feels comfortable when she stays with Australian relatives (line 2), showing that she gets accustomed to western culture to some degree. Plus, Kola thinks that she loves western movies and singers, especially Harry Potter movies, which are her favorite (line 4-6). Identities are related to the imagination and then the internalization of the agencies (Anderson, 1983), constructed through a process of individuation (Giddens, 1991). Hence, the process of identity construction is a relatively subjective activity, relying on the internal causes mostly rather than triggered by external environments. In terms of Kola's identity related to English, it is her inner sense of identity that works to get close to the Western culture. To be more specific, Kola's inner passion for western movies represents her affirmation and identification of western culture, suggesting that Kola tends to identify more with western identity culturally.

Meanwhile, Kola has a bad impression of Mainland Chinese culture through the mass media, regarding the movies that are not worthy to watching (line 7). This feeling is so strong that Kola shows her attitude directly, "I don't like it" (line 8), which is an evaluation presenting her dislike and hates to the movies. In Hong Kong's popular media, Mainland Chinese is stigmatized as 'uncivilized' and 'uneducated' outsiders and intruders, thus drawing a comparison with the 'civilized' and 'educated' Hong Kong (Fung, 2004). As Jackson (2014) points out, from a very young age, we begin to form our identities through primary socialization including the family, education system, and mass media, which plays important parts in determining what we will be as social members. If the mass media has a clear direction as mentioned above, then Kola's unwillingness to contact Mainland Chinese artistic work is reasonable. Similarly, if the mass media has a clear direction to show the civilization and prosperity of the Western culture, then Hong Kong people would tend to admire the Western culture and lifestyles, as well as identity.

Extract 4 below shows the difference that Kola identified from Americans.

1) I vividly remembered my teacher taught me English in British accent.

2) And when I did my homework in American English or
Australian English,

3) They said it was not correct, even if there were no grammatical mistakes or misspelling.

4) I was very confused.

5) Because I didn't understand why they insisted only British English is acceptable.

6) Every actor in the soap drama I watched is speaking American English.@@

7) But I'm not courageous enough to challenge them so I stopped using American English.

8) When I was in primary 4, I went to US for an exchange.

9) And my host family sometimes didn't understand my British English.

10) It was so unforgettable.

11) Once I told them what is "rubbish" for almost an hour!

12) Because I wanna to throw my rubbish in a rubbish bin.

13) After a long time, they finally got it and they told me rubbish in America is called "garbage".

14) I was then realized there was no "correct" English.

15) But I still don't know why the older generation,

16) Like my teacher from primary school, only accept British English.

17) They even hoped us to have British accent and think it is proud to have British accent.

Using the same framework, extract 3 also constitutes the following segments of the structure:

Orientation: Kola stated that the event happened under the condition that she went to the U.S. for an exchange (line 8), specifying the time period and the location.

Abstract: The American host family did not understand some words from British English, e.g., "rubbish" (line 9), thus producing a skirmish of throwing rubbish.

Actions: Kola described the communication about "rubbish" with the American host family (line 11-13) and explained why this situation would happen. The reason is Kola received a British English education at school in Hong Kong, and the teachers insisted that British English was the only correct and standard English (line 1-3).

Evaluation: Kola evaluated the teacher's behavior and explained her transitions of the attitudes to the "correct" English. She was confused in Hong Kong (line 4-5), but after the experience in the U.S., she got to know there was no socalled "correct" English (line 14). 
Resolution: The teachers insisted their original opinion, so Kola stopped using American English because she was not brave enough (line 7).

Coda: Kola proposed that she is still confused about the older generation who insists to apply the British accent and force the young generation to use it as well (line 15-17).

In this narrative, there are two critical events. One is about the "rubbish" issue in an American host family, and another is about the British English education system in Hong Kong. The latter is an explanation of the former. Since the education system is also a crucial part to influence our identity perception (Jackson, 2014), Kola has received the education that British English is correct and more superior, thus forming a perception that British English is more closely to "standard English". As Kola is very young, it is very difficult to challenge authority. Even though Kola was immersed in American culture (movies), Kola still built her identity as British English rather than American or Australian. This event has further enhanced Kola's perception of identity that related to the British, and she also found the difference form the Americans, which implies that her identity is only related to British English identity, not a fully western cultural identity.

Extract 5 demonstrates Kola's identity as a local Hongkonger.

1) I think HK has its own style.

2) Like it's a hybrid of Eastern and Western culture.

3) For pop cultures, I think it's more like the west.

4) But we do have some festivals like Mainland China.

5) It's complicated, but I think Hong Kong is unique and I'm proud of who I am.

This narrative presents that Kola regards herself as a Hongkonger identity which involves a mixture of the Western (British) culture and the Eastern (Mainland China) culture. As said (2001) points out, the connection between the countries and the districts are "between the two spheres". Hongkonger is in an embarrassing position. From a cultural point of view, it can belong to Chinese identity and is also influenced by British identity. When it comes to cultural heritage and the thousand years of history, they tend to refer to the Chinese identity. The British identity is more referred to as lifestyle. Due to the Chinese identity, they are expelled by the British community and vice versa. It might be the reason that localism keeps rising for decades (Veg, 2017). As Kola explains, Hongkong is unique and they have a dual identity which is a cultural hybrid, also known as "in-between hybridity" (Bhabha, 2012). According to Bhabha (2012), every cultural community has its own boundary, and the marginal space is "in-between hybridity". For example, Hong Kong is an "inbetween" space where produces numerous cultural hybrids. On the one hand, they are desirable to belong to a group, whatever it is British or Chinese. On the other hand, they are different from any cultural community, because they have the cultural imprint of another group, which shows their difference to others. As a result, they are like cultural orphans wandering on the cultural margins.

\section{Conclusion}

In conclusion, this study aims to investigate how a young generation Hongkonger constructs her identity in a postcolonial context and provides evidence of the dual and hybrid identity of Hongkongers. Based on the analytical framework according to Labov and Waletzky's (2003), the narrative data were analyzed related to specific elements, including abstract, orientation, complicating action, evaluation, resolution, and coda. The participant feels sameness and difference with British culture and Mainland Chinese culture respectively, indicating the identity is dual and complex. Since Hong Kong is an "in-between" place, located in the cultural margins, it is ambiguous to define which cultural community it belongs to. As a group that grew up in such a unique area, Hongkonger's identity is contradictory and separated. On the one hand, they are desirable to seek permission which allows them to belong to a certain cultural community. On the other hand, they are willing to construct their identity through their own efforts, resulted in the rise of localism, which exclaims that Hong Kong is independent from a cultural point of view. Hence, as Kola argues, Hong Kong has its own culture which is hybridity of the Western culture (British) and the Eastern culture (Mainland China).

Moreover, due to the limitation of data size and the researcher's experience, this research lacks detailed data to analyze Hongkonger's identity. Also, this study only adopts one narrative enquiry from a participant, so all of the evidence is around the interviewee's identity, which remains uncertain to reflect all Hongkonger's situation. More research needs to be conducted to provide evidence of Hongkonger's special and complicated sense of cultural identity.

\section{References}

[1] Anderson, B. (1983). Imagined communities: Reflections on the origin and spread of nationalism. London: Verso.

[2] Beijaard, D., Meijer, P. C., \& Verloop, N. (2004). Reconsidering research on teachers' professional identity. Teaching and teacher education, 20(2), 107128.

[3] Benatti, R., \& Tarantini, A. T. (2018). Dialects among young Italian-Australians: A shift in attitude and perception. Studia Anglica Posnaniensia: international review of English Studies, 52.

[4] Bhabha, H. K. (2012). The location of culture. Routledge.

[5] Bond, M. H., \& King, A. Y. (1985). Coping with the threat of westernization in Hong Kong. International Journal of Intercultural Relations, 9(4), 351-364.

[6] Fung, A. (2004). Postcolonial Hong Kong identity: Hybridising the local and the national. Social Identities, 10(3), 399-414.

[7] Giddens, A. (1991). Modernity and self-identity: Self and society in the late modern age. Stanford university press.

[8] Hobova, Y. (2016). Chinese in Hong Kong: cultural and linguistic background of two identities. International Communication of Chinese Culture, 3(2), 325-337.

[9] Jackson, J. (2014). Introducing Language and Intercultural Communication. Milton Park, Abingdon: Routledge. 
[10] Labov, W., \& Waletzky, J. (2003). Narrative analysis: Oral versions of personal experience. Seattle: University of Washington Press.

[11] Oberg, K. (1960). Cultural shock: Adjustment to new cultural environments. Practical anthropology, (4), 177182.

[12] Webster, L., \& Mertova, P. (2007). Using narrative inquiry as a research method: An introduction to using critical event narrative analysis in research on learning and teaching. Routledge.

[13] Veg, S. (2017). The rise of "localism" and civic identity in post-handover Hong Kong: Questioning the Chinese nation-state. The China Quarterly, 230, 323-347.

\section{Appendix: Questions}

Where were you born and how old are you?

What language(s) did you grow up with in the home?

What language(s) did you speak in and write in at school in your formal classes?

What language(s) did you use in the playground with your friends?

What language(s) did you speak with your friends at home?

Is there a particular language you enjoy using? If so, what is it?

When do you use it? With whom?

How does it make you feel?

Do you have any memories about the first time you heard someone speak in a language you were unfamiliar with?

What can you remember about this?

What is your first memory of realising that not all people speak the same language or follow the same cultural traditions?

When did you first travel overseas?

What was this like?

Have you experienced some different events? 